\title{
QUAL SERÁ O FUTURO DO GÊNERO HUMANO?
}

\author{
Maria das Graças Targino a
}

A ciência da informação $(\mathrm{Cl})$ configura-se como o conjunto de conhecimentos relativos à origem, à coleta, à organização, ao armazenamento, à recuperação, à interpretação, à transferência, à transformação e à utilização da informação, ou seja, refere-se a todo o ciclo informacional. Recorre à representação da informação em sistemas naturais ou artificiais, a técnicas e meios diversificados de processamento, com ênfase nas tecnologias de informação e de comunicação, a fim de assegurar a otimização do fluxo de informação com qualidade, o que pressupõe rapidez, atualidade, consistência, confiabilidade e abrangência, aliados à facilidade de acesso às fontes e aos documentos primários. Logo, como resultante do seu próprio objeto de estudo a informação - presente em todas as áreas do conhecimento humano, a $\mathrm{Cl}$ assume inevitável caráter interdisciplinar e transdisciplinar, haja vista que a informação está presente nos mais diferentes campos do conhecimento humano.

Não é à toa que os autores Hamilton Viana Chaves e Osterne Nonato Maia Filho, apoiados em sua formação interdisciplinar - psicologia e educação - descrevem, com propriedade, a relevância do fluxo de informações no avanço da ciência e tecnologia (C\&T), na obra lançada em dezembro de 2019, sob encargo editorial da Lisbon International Press e intitulada "Sociedade e conhecimento: acerca do futuro do gênero humano". A informação está associada às demais necessidades humanas de sobrevivência - fisiológicas, afetivas e cognitivas - uma vez que é ela função básica que permite aos seres vivos reconhecerem a realidade a fim de satisfazerem as condições de vida e a perpetuação da espécie. Todos os seres vivos se informam. A busca e a

\footnotetext{
a Doutora em Ciência da Informação pela Universidade de Brasília (UnB). E-mail: gracatargino@hotmail.com.
} 
apreensão da informação independem da capacidade de percepção, da reflexão e do raciocínio. A semente que trata de descobrir elementos químicos para a germinação ou a planta que rompe a crosta da terra em busca da luz do sol estão se informando, tal como o cão que fareja um rastro, um gato que "sente" a presença de outro, um bebê recém-nascido que reage instintivamente à claridade. Porém, há visível distinção entre as modalidades de informação. Por exemplo, a informação presente numa molécula de DNA e aquela que, indo além do instinto inato de sobrevivência, é "construída" pelo homem para agir como fator de integração individual e social, estão em níveis diferenciados, reiterando as palavras literais dos autores, para quem:

Conhecimento não é uma coisa. É uma dimensão do ser humano: e ele não existe sem o conhecimento. Na natureza há informação (bits), mas não conhecimento, assim como na natureza há troca de informações, mas não há comunicação: uma árvore troca informações com o solo, mas os dois não se comunicam. É como dizer que temos três vidas: uma pessoal, individual, que vai do nosso nascimento até a morte. Simultaneamente, há uma social, no sentido estrito, relativo às trocas sociocomunicativas que nos entrelaçam uns com os outros e, através das quais nos tornamos o que somos. Finalmente, e é aí que o conhecimento intervém, há uma dimensão na qual cada um de nós dá sua contribuição (pequena ou grande) à história da Humanidade (p. 11).

Dizendo de outra forma, o conhecimento é um corpo sistemático de informações adquiridas e, então, não mais encapsuladas, que permite ao indivíduo compreender a natureza. É através da apreensão que o ser humano transmuta informação em conhecimento. Retomando o exemplo dos dados repassados diariamente pela mídia, só é conhecimento a parcela, mesmo que ínfima, dos elementos que causam alterações no repertório cognitivo e conceitual do ser humano. Dentre o manancial de informações às quais se tem acesso, só o que se consegue reter, assimilar e compreender é conhecimento.

E é a partir dessa visão, que Hamilton Chaves e Osterne Maia refletem acerca do futuro da Humanidade, tratando do incremento da construção de novos saberes via C\&T, haja vista que as tecnologias exercem forte efeito, sem nenhuma exceção, sobre todos os segmentos da vida do homem contemporâneo, gerando novos cenários e consolidando a chamada sociedade da informação, a qual recebe uma série de denominações, a exemplo de 
modernidade tardia, pós-modernidade, sociedade do ócio, modernidade líquida e outros cognomes, a depender da linha teórica adotada. Por exemplo, na visão do sociólogo polonês Zygmunt Bauman, a sociedade líquida caracteriza-se pela fragilidade e/ou dissolução das forças que garantiriam os padrões sociais de referência, hoje, liquefeitos e voláteis, face ao intenso fluxo informacional, responsável "[...] pela formatação de outro cenário, de tal modo que tem impactado as relações sociais, na gestão do conhecimento e na produção de bens materiais" (p. 83).

Aliás, na "nova" sociedade, independentemente da terminologia adotada, o eixo da economia passa a ser a produção, distribuição e difusão da informação, consolidando um setor emergente do sistema produtivo, o quaternário, o qual incorpora as atividades relativas à indústria da informação e do conhecimento. Isto é fácil de perceber quando da análise da força da informação no momento atual. A sociedade é submetida a uma avalanche de dados vindos de meios tradicionais, como o livro, a revista, o jornal, o rádio, a tevê ou de sofisticados recursos, como as redes eletrônicas de informação, tendo quem afirme que tudo é informação e que as ações humanas se reduzem a ela, considerando-se até mesmo o desconhecido como informação-potencial.

Em tom ensaístico, distante do academicismo exacerbado, os autores discorrem, ao longo de 94 páginas, sobre a trajetória que marca a formação da sociedade da informação em suas diferentes facetas, em meio à profunda reflexão acerca de nosso futuro. Para tanto, consideram a evolução sistemática e contínua da atividade cognitiva e social (inerente ao indivíduo), evidenciando seus aspectos racionais ou não. Como inevitável, lançam mão do pensamento de experts, a exemplo do sociólogo italiano Andrea Cerroni, Università degli Studi di Milano-Bicocca, autor de uma série de livros sobre sociedade e C\&T; do holandês Baruch de Espinosa, parceiro das ideias de grandes filósofos, como René Descartes. Sigmund Freud, o "Pai da Psicanálise"; o psicanalista francês Jacques [Marie Émile] Lacan; o revolucionário socialista Karl Marx, nascido na Prússia e, posteriormente, declarado apátrida; o tunisiano Pierre Lévy, um dos estudiosos mais relevantes sobre o impacto da internet no futuro do gênero humano, estão também entre os autores consagrados e citados. 
Na seção inicial, a abordagem contempla a sociedade e o indivíduo como ser social, mas único em sua sociabilidade, porquanto é ela marcada por sua história de vida e sua capacidade de assimilar. Discorrem, então, sobre concepções seminais, que incorporam o conhecimento e a citada sociedade do conhecimento, os artefatos de conhecimento, sejam eles de natureza material ou simbólica, verificando o possível esgotamento do pensamento moderno e, por conseguinte, a emergência de outro status para o ser humano. A este respeito, os professores Hamilton Chaves e Osterne Maia deixam claro que se fundamentam na "[...] análise da psicologia subjacente ao nascimento e [à] materialização do Estado moderno [...]" (p. 39), reforçando a ideia de que a modernidade não separa o homem do trabalho. Afinal, conhecimento, arte e trabalho caminham rumo ao processo de humanização da coletividade.

A Parte II, por sua vez, se detém, a priori, a trabalhar o conceito de governança e sustentabilidade do conhecimento, uma vez que tal governança precisa levar em conta diferentes dimensões, quais sejam, psíquica, gnosiológica, ontológica, etc. com o intuito de assegurar a sustentabilidade do gênero humano. Ademais, espera-se que o fluxo informacional e a circulação do conhecimento garantam a democratização informacional. No entanto, a bem da verdade, a democratização das informações e a estratificação social menos desigual são mais aparentes do que verdadeiras, porquanto mantêm atrelamento ostensivo com o poder da comunicação científica, ou seja, "tornar capital o conhecimento investido pode [...] gerar novas desigualdades em nível social, assim como amplificar as desigualdades existentes" (p. 11). O gerenciamento das informações continua submetido a critérios governamentaisprivados, sem interferência do grande público. E mais, as disparidades entre países e regiões persistem, como os psicólogos e educadores Hamilton Chaves e Osterne Maia afirmam, não obstante três elementos intrínsecos ao gênero humano - necessidades, intenções e desejos:

Neste caso, a comunicação da ciência não cumpriria seu papel e não democratizaria o conhecimento como um bem social. Eis um [...] risco para a ciência atual: seu crescimento e validade metodológica, teórica, e suas aplicações, que dependem [...] do controle público, seu fundamento primeiro; no entanto, a ciência parece estar cada vez mais associada à sua privatização [...] (p. $52)$. 
$\mathrm{Na}$ Parte III, a que se seguem as notas conclusivas, "Sociedade e conhecimento: acerca do futuro do gênero humano" prioriza o cenário que marca a sociedade do conhecimento e, adiante, apresenta alguns de seus paradoxos e suas convergências, com ênfase para a interdisciplinaridade inerente à informação, como antes visto, e às áreas de conhecimento, como psicologia, psicanálise, sociologia, educação, $\mathrm{Cl}$, física, matemática e outras. Porém, em qualquer circunstância, não se pode relegar a evolução da atividade sociocognitiva com o risco de o indivíduo e sua inter-relação com os demais situarem-se fora do mundo fenomenológico. Essa perspectiva de governança conduz à percepção de que qualquer conhecimento pode ser codificado, não importa o ser humano envolvido no processo: "[...] a individualidade [...] passaria a ser apenas um conceito, eliminando a lógica da própria cultura como um sistema aberto e produtor de diferentes subjetividades" (p. 66), o que, talvez, justifique a inserção de uma análise de caso referente à música.

É evidente que os autores defendem a ideia de que a análise mais completa e acurada acerca do futuro do gênero humano não pode estar restrita à racionalidade. Se assim for, ao priorizar e/ou enaltecer ostensivamente a sociedade digital, há o risco de se eliminar os sustentáculos da cultura humana, irreversivelmente dinâmica e aberta. O exacerbamento dessa nova cultura conduzirá ao "[...] eterno retorno de repetidos pensamentos, como na compulsão traumática à repetição". Pergunta-se: "em que isto contribui para a sustentabilidade do gênero humano?" (p. 85). Qual será o futuro do gênero humano? Eis uma questão que persiste sem respostas unívocas ou conclusivas, mas que requer reflexões de qualidade, como a conduzida pelos educadores Hamilton Chaves e Osterne Maia.

\section{REFERÊNCIAS}

TARGINO, M. das G. Qual será o futuro do gênero humano? Recensão da obra de: CHAVES, H.; MAIA, O. Sociedade e conhecimento: acerca do futuro do gênero humano. Lisboa: Lisbon International Press, 2019. 94 p.

Recebido em: 22.02.2020

Aceito em: 04.07.2020 